\title{
KONKURENCYJNOŚĆ WOJEWÓDZTWA PODKARPACKIEGO NA TLE INNYCH REGIONÓW POLSKI WSCHODNIEJ
}

\begin{abstract}
W artykule podjęto problem konkurencyjności regionów, w tym zwłaszcza konkurencji międzyregionalnej, oraz dokonano analizy konkurencyjności województwa podkarpackiego na tle innych województw Polski Wschodniej (rozumianych zgodnie z nomenklaturą Programu Operacyjnego Rozwój Polski Wschodniej województwami: warmińskomazurskim, lubelskim, podkarpackim, podlaskim i świętokrzyskim). Ocenę konkurencyjności badano przy użyciu metody rangowania. Pojęcie konkurencyjności definiowane jest przez wielu autorów jednak najczęściej w odniesieniu do przedsiębiorstw.

Konkurencyjności regionów jako pojęcie ekonomiczne funkcjonuje relatywnie od niedawna, w związku z czym nie sprzyja to jednoznacznemu jej definiowaniu, a tym bardziej określeniu jej mierników. Na potrzeby niniejszej pracy badano konkurencyjność regionów na podstawie kilkunastu mierników charakteryzujących różne aspekty poziomu rozwoju gospodarczego. Wśród tych mierników były między innymi PKB per capita, nakłady na badania i rozwój, liczba przedsiębiorstw ponoszących nakłady na działalność innowacyjną oraz atrakcyjność inwestycyjna województw. W przeprowadzonej analizie konkurencyjności regionów wykazano, że PKB per capita nie jest czynnikiem decydującym o pozycji konkurencyjnej województwa podkarpackiego. Oznacza to, że region może mieć wysoki poziom wskaźnika konkurencyjności mimo niskiego wskaźnika PKB na osobę. Za słusznością takiej tezy przemawia przykład województwa podkarpackiego, które jest liderem pod względem nakładów własnych w sektorze przedsiębiorstw na działalność badawczo-rozwojową, a także w liczbie przedsiębiorstw przemysłowych, które współpracowały $\mathrm{w}$ zakresie działalności innowacyjnej. Jest to przy tym region charakteryzujący się jednym z najniższych wskaźników PKB na 1 mieszkańca.

Słowa kluczowe: konkurencyjność regionów, regiony Polski Wschodniej, województwo podkarpackie, metoda rangowania, regiony peryferyjne
\end{abstract}

\section{WPROWADZENIE}

Do regionów Polski Wschodniej należą województwa: podkarpackie, warmińskomazurskie, lubelskie, podlaskie i świętokrzyskie. Wszystkie te regiony zaliczają się do tak zwanych regionów peryferyjnych pod względem gospodarczym. Jako główne cechy peryferyjności Tadeusz Kudłacz wymienia między innymi ${ }^{2}$ :

1. niski poziom produktu krajowego brutto (PKB) na jednego mieszkańca;

\footnotetext{
${ }^{1}$ Mgr Witold Czudec, doktorant Wydziału Ekonomicznego, Uniwersytetu Marii Curie-Skłodowskiej w Lublinie, e-mail: witold.czudec@live.umcs.edu.pl

${ }^{2}$ T. Kudłacz, Analiza pięciu strategii regionalnych województw Polski wschodniej i problemów stykowych pomiędzy województwami Polski wschodniej z innymi regionami, Ministerstwo Rozwoju Regionalnego, Warszawa 2006, http://www.mrr.gov.pl/rozwoj_regionalny/poziom_regionalny/strategia_rozwoju_polski_ wschodniej_do_2020/zespol_ds_strategii/Documents/Analiza_5_strategii_regionalnych_kudlacz.pdf (dostęp: 11.03.2010).
} 
2. niekorzystną strukturę zatrudnienia;

3. niską innowacyjność gospodarki;

4. niską atrakcyjność inwestycyjną.

Aby przyspieszyć procesy rozwojowe tych obszarów, w latach 2007-2013 dedykowano dla nich Program Operacyjny Rozwój Polski Wschodniej, którego celem było „Przyspieszenie tempa rozwoju społeczno-gospodarczego Polski Wschodniej w zgodzie z zasadą zrównoważonego rozwoju",3. Również w najbliższej perspektywie finansowania z Funduszy Europejskich 2014-2020 przewidziany jest program operacyjny zwiększający skuteczność polityki rozwojowej tych województw.

Mając to na uwadze, w artykule podjęto próbę scharakteryzowania czynników decydujących o poziomie konkurencyjności województwa podkarpackiego na tle innych regionów Polski Wschodniej. Na podstawie przyjętych czynników przygotowano ranking konkurencyjności województw Polski Wschodniej. Analizę przedstawionego problemu przeprowadzono $\mathrm{z}$ wykorzystaniem danych liczbowych publikowanych przez Główny Urząd Statystyczny (Bank Danych Lokalnych, Regiony Polski). Wykorzystano także dane liczbowe publikowane przez Europejski Urząd Statystyczny.

Analizę konkurencyjność regionów przeprowadzono przy użyciu metody unitaryzacji zerowej, dzięki czemu uzyskano normalizację cech diagnostycznych. Konkurencyjność regionów badano w ujęciu dynamicznym, czyli w latach 2006 i 2011. Metoda unitaryzacji zerowej należy do grupy metod wielowymiarowej analizy statystycznej, które coraz częściej znajdują zastosowanie $\mathrm{w}$ badaniach realizowanych na potrzeby gospodarki ${ }^{4}$. Efektem normalizacji mierników liczbowych jest uzyskanie dla nich wartości zawierającej się w przedziale domkniętym $<0: 1>$. Zdecydowano się na zastosowanie tej metody ze względu na:

1. ujednolicenie charakteru zmiennych i ujednolicenie ich zakresu do przedziału < 0:1 > dzięki wykorzystaniu odpowiednich wzorów;

2. możliwości sprowadzenia zmiennych o różnych zakresach do wzajemnej porównywalności;

3. wyeliminowanie wartości ujemnych.

Standaryzacji dokonano za pomocą wzorów:

dla stymulant:

$z_{i}=\frac{x_{i}-\min x_{i}}{R\left(X_{i}\right)}$,

dla destymulanty:

$z_{i}=\frac{\max x_{i}-x_{i}}{R\left(X_{i}\right)}$

${ }^{3}$ Program Operacyjny Rozwój Polski Wschodniej 2007-2013. Narodowe Strategiczne Ramy Odniesienia 20072013, Ministerstwo Rozwoju Regionalnego, Warszawa 2012.

${ }^{4}$ A. Walenia, Zastosowanie metody statystycznej unitaryzacji zerowej do oceny możliwości absorpcji środków Unii Europejskiej przez sektor samorzqdowy Podkarpacia, „Studia i Prace Kolegium Zarządzania i Finansów” 2009/91. 
gdzie:

$z_{i}-$ zmienna po znormalizowaniu,

$x_{i}$ - wartość zmiennej,

min $x_{i}$ - minimalna wartość zmiennej,

$\max x_{i}$ - maksymalna wartość zmiennej,

$\mathrm{R}\left(X_{i}\right)$ - różnica pomiędzy wartością maksymalną i minimalną zmiennej.

\section{PROBLEM KONKURENCYJNOŚCI REGIONÓW W ŚWIETLE LITERATURY}

Jak zauważa Obrębski: „,konkurencyjność regionalna jako kategoria ekonomiczna jest relatywnie młoda, co nie sprzyja jednoznacznej jej definicji ani też jednoznacznemu określeniu mierników" . W literaturze przedmiotu istnieje wiele definicji konkurencyjności, jednak większość z nich odnosi się do przedsiębiorstw. Najogólniej mówiąc, konkurencyjność jest to proces, w którym podmioty na rynku dążą do realizacji swoich interesów, przedstawiając oferty korzystniejsze niż konkurencja. Michael Porter, ojciec teorii konkurencyjności, choć w swoim dziele The Competitive Advantage of Nations opisuje procesy konkurencyjności, to nie definiuje konkretnie tego zjawiska. Rozwój teorii oraz badania nad konkurencyjnością gospodarki prowadzą do bardziej kompleksowego ujęcia tego tematu - zmierzaja do jego badania w skali makroekonomicznej, a nawet globalnej. Pojęcie „konkurencyjność” odnosi się również do gospodarki jako układu terytorialnego, definiując je przykładowo jako „zdolność do długotrwałego i efektywnego wzrostu w warunkach gospodarki otwartej, przy czym zachodzące $w$ niej zmiany strukturalne powinny być zgodne $\mathrm{z}$ tendencjami obserwowanymi w gospodarce światowej”. Jak zauważa Surówka: „konkurować mogą ze sobą nie tylko przedsiębiorstwa, ale również województwa, powiaty i gminy. Aby województwo było konkurencyjne, powinno wzbudzać zainteresowanie wśród potencjalnych klientów, którymi mogą być mieszkańcy, inwestorzy, turyści, wczasowicze, osoby zainteresowane zmianą miejsca zamieszkania" ${ }^{\text {"7 }}$. O konkurencyjności regionu decyduja: postęp technologiczny, innowacje (zarówno krajowe, jak i zagraniczne; publiczne i prywatne), systemy zarządzania oraz korzyści skali ${ }^{8}$. Szczególne znaczenie zyskują dostęp i poziom kształcenia oraz technika, które odzwierciedlają poziom konkurencyjności technologicznej.

W dokumentach Komisji Europejskiej, jak również innych organów Unii Europejskiej konkurencyjność regionu oznacza podnoszenie jego poziomu rozwoju społecznogospodarczego. Jak pisze Pietrzyk, szósty okresowy raport Komisji Europejskiej określa

\footnotetext{
${ }^{5}$ M. Obrębski, Mierniki rozwoju regionalnego, [w:] Metody oceny rozwoju regionalnego, red. Strahl D., Wydawnictwo Akademii Ekonomicznej we Wrocławiu, Wrocław 2006.

${ }^{6}$ W. Bieńkowski, Reaganomika i jej wptyw na konkurencyjność gospodarki amerykańskiej, PWN, Warszawa 1995.

7 A. Surówka, Badanie zróżnicowania województw pod względem konkurencyjności, „Zeszyty Naukowe Uniwersytetu Rzeszowskiego", Rzeszów 2007.

${ }^{8}$ A. Olesiuk, Konkurencyjność regionów a parki technologiczne i klastry przemystowe, Oficyna Wydawnicza Branta, Bydgoszcz-Warszawa 2009.
} 
to pojęcie jako ,zdolność regionów, wystawionych na konkurencję międzynarodową do osiaggania relatywnie wysokiego poziomu dochodów i zatrudnienia"9.

Regionalna polityka konkurencyjności polega na aktywizacji czynników wewnątrz regionu, czyli szczególnych cech wyróżniających dany region spośród sąsiednich obszarów terytorialnych. Czynniki te mogą, często przy pomocy zewnętrznego wsparcia zwłaszcza finansowego - determinować budowę potencjału konkurencyjnego regionu, decydując o jego poziomie atrakcyjności. Do takich czynników można zaliczyćc ${ }^{10}$ :

1. strukturę gospodarki, w której wyróżniają się gałęzie i przedsiębiorstwa zdolne do wewnątrzkrajowej i międzynarodowej rywalizacji z konkurentami. Dzięki nie tylko specjalizacji produkcji, ale również usług możliwy jest rozwój regionu na podstawie teorii produktu podstawowego;

2. inwestycje - bez względu na źródło ich pochodzenia, z którymi konkurencyjność regionu jest bezpośrednio powiązana i są zależne od siebie; wzrost inwestycji podnosi konkurencyjność, która przyciąga nowe inwestycje;

3. infrastrukturę techniczną - ze szczególnym uwzględnieniem infrastruktury telekomunikacyjnej i informatycznej, która wspomaga pozyskiwanie, przetwarzanie i przekazywanie informacji w coraz krótszym czasie;

4. infrastrukturę społeczną - czyli system edukacji, ochronę zdrowia, pomoc społeczną i inne. Wpływa ona na jakość zasobów siły roboczej w regionie;

5. działalność badawczo-rozwojową $(B+R)$ - czyli występujące w danym obszarze placówki naukowo-badawcze, jednostki badawczo-rozwojowe, szkoły wyższe itp., które sprzyjają powstawaniu innowacji;

6. środowisko naturalne regionu - przyjazne zamieszkaniu, pracy i odpoczynkowi. Działania samorządu powinny być nakierowane na proekologiczne przedsięwzięcia, chroniące dobro naturalne;

7. instytucje okołobiznesowe - inkubatory przedsiębiorczości, klastry, izby gospodarcze, agencje rozwoju regionalnego, fundusze doręczeniowe itp., które działają pośrednio na wymienione czynniki, wzmacniając ich oddziaływanie.

\section{ANALIZA POZIOMU KONKURENCYJNOŚCI REGIONÓW}

Istnieje wiele metod i mierników poziomu konkurencyjności regionów, mierzących między innymi jego innowacyjność, poziom życia mieszkańców oraz atrakcyjność dla inwestorów. Na potrzeby niniejszego artykułu wybrano trzynaście cech, które zdaniem autora opisują poziom konkurencyjności regionu w ujęciu gospodarczym. Są to:

1. Wartość nakładów inwestycyjnych ogółem (tys. zł);

2. Nakłady inwestycyjne na 1 mieszkańca (zł);

3. Nakłady na B + R per capita (mln zł);

4. Przedsiębiorstwa przemysłowe, które współpracowały w zakresie działalności innowacyjnej (\% ogółu przedsiębiorstw);

5. Bezrobotni zarejestrowani pozostający bez pracy dłużej niż rok (\% ludności aktywnej zawodowo);

6. Jednostki z działalnością badawczo-rozwojową ogółem (jd);

\footnotetext{
${ }^{9}$ I. Pietrzyk, Polityka regionalna Unii Europejskiej i regiony w państwach członkowskich, PWN, Warszawa 2000.

${ }^{10}$ A. Olesiuk, op. cit.
} 
7. Jednostki z działalnością badawczo-rozwojową w sektorze przedsiębiorstw (jd);

8. Zatrudnieni w B + R ogółem (EPC);

9. Zatrudnieni w B + R w sektorze przedsiębiorstw (EPC);

10. Nakłady własne w sektorze przedsiębiorstw na działalność $B+R$ (tys. zł.);

11. PKB per capita (zł);

12. Przedsiębiorstwa, które poniosły nakłady na działalność innowacyjną (\% przedsiębiorstw w przemyśle);

13. Atrakcyjność inwestycyjna województwa.

Spośród wymienionych czynników charakteryzujących konkurencyjność regionu można wyróżnić dwie grupy. Jedna to stymulanty konkurencyjności - są to zmienne, dla których wysokie wartości powodują wzrost konkurencyjności regionu. Do grupy tej zaliczono dwanaście czynników. Druga grupa to destymulanty - są to zmienne, dla których wyższa wartość oznacza pogorszenie pozycji konkurencyjnej regionu (z punktu widzenia ogólnej charakterystyki problematyki konkurencyjności wysokie wartości są niepożądane). W badanej grupie wskaźników oznaczono tylko jedną destymulantę. W tabeli 1 ukazano podział mierników ze względu na ich wpływ na konkurencyjność.

Tabela 1. Podział mierników według ich wpływu na konkurencyjność regionu

\begin{tabular}{|l|l|l|}
\hline $\mathrm{x}_{1}$ & PKB per capita & Stymulanta \\
\hline $\mathrm{x}_{2}$ & Wartość nakładów inwestycyjnych ogółem & Stymulanta \\
\hline $\mathrm{x}_{3}$ & Nakłady inwestycyjne na 1 mieszkańca & Stymulanta \\
\hline $\mathrm{x}_{4}$ & Nakłady na B + R per capita & Stymulanta \\
\hline $\mathrm{x}_{5}$ & Nakłady własne w sektorze przedsiębiorstw na działalność B + R & Stymulanta \\
\hline $\mathrm{x}_{6}$ & $\begin{array}{l}\text { Przedsiębiorstwa przemysłowe, które współpracowały w zakresie } \\
\text { działalności innowacyjnej }\end{array}$ & Stymulanta \\
\hline $\mathrm{x}_{7}$ & $\begin{array}{l}\text { Przedsiębiorstwa, które poniosły nakłady na działalnośćć } \\
\text { innowacyjną }\end{array}$ & Stymulanta \\
\hline $\mathrm{x}_{8}$ & Jednostki z działalnością badawczo-rozwojową ogółem & Stymulanta \\
\hline $\mathrm{x}_{9}$ & $\begin{array}{l}\text { Jednostki } \mathrm{Z} \quad \text { działalnością badawczo-rozwojową w sektorze } \\
\text { przedsiębiorstw }\end{array}$ & Stymulanta \\
\hline $\mathrm{x}_{10}$ & Bezrobotni zarejestrowani pozostający bez pracy dłużej niż rok & Destymulanta \\
\hline $\mathrm{x}_{11}$ & Zatrudnieni w B $+\mathrm{R}$ ogółem & Stymulanta \\
\hline $\mathrm{x}_{12}$ & Zatrudnieni w B + R w sektorze przedsiębiorstw & Stymulanta \\
\hline $\mathrm{x}_{13}$ & Atrakcyjność inwestycyjna województwa & stymulanta \\
\hline
\end{tabular}

Źródło: opracowanie własne

\section{ANALIZA POZIOMU KONKURENCYJNOŚCI WOJEWÓDZTWA PODKARPACKIEGO}

Ocenę poziomu konkurencyjności województwa podkarpackiego na tle pozostałych regionów Polski Wschodniej podzielono na dwie części. Pierwsza z nich ukazuje wartości znormalizowane dla poszczególnych zmiennych, w drugiej dokonano podsumowania wartości wszystkich miar oraz na podstawie tego wyliczono ranking konkurencyjności. Dane pokazywane są dla roku 2006 i 2011 (o ile są już dostępne).

Najpopularniejszym wskaźnikiem makroekonomicznym wykorzystywanym w ocenie poziomu rozwoju gospodarczego, a zarazem ukazującym stan gospodarki regionu jest 
PKB per capita, który przedstawiono w tabeli 2. Najaktualniejsze dane dotyczące tego wskaźnikach pochodzą z roku 2010.

Tabela 2. Produkt krajowy brutto na 1 mieszkańca $\left(\mathrm{x}_{1}\right)$

\begin{tabular}{|l|c|c|}
\hline \multirow{2}{*}{} & \multicolumn{2}{|c|}{$\mathbf{x}_{\mathbf{1}}$} \\
\cline { 2 - 3 } & 2006 & 2010 \\
\hline Lubelskie & 0,000 & 0,033 \\
\hline Podkarpackie & $\mathbf{0 , 1 0 4}$ & $\mathbf{0 , 0 0 0}$ \\
\hline Podlaskie & 0,688 & 0,637 \\
\hline Świętokrzyskie & 1,000 & 1,000 \\
\hline Warmińsko-mazurskie & 0,947 & 0,714 \\
\hline
\end{tabular}

Źródło: opracowanie własne na podstawie metody unitaryzacji zerowej

Województwo podkarpackie w tej kategorii obniżyło swoją pozycję z wartości 0,104 w roku 2006 do wartości $0,000 \mathrm{w}$ roku 2010, co oznacza najgorszą pozycję ze wszystkich badanych województw (nastąpiła zamiana pozycji z województwem lubelskim). Liderem w tej kategorii w roku 2006 i 2010 było województwo świętokrzyskie.

W tabeli 3 zobrazowano wartości nakładów inwestycyjnych oraz nakładów na działalność badawczo-rozwojową.

Tabela 3. Wartość nakładów inwestycyjnych ogółem $\left(\mathrm{x}_{2}\right)$, nakłady inwestycyjne per capita $\left(\mathrm{x}_{3}\right)$, nakłady na działalność badawczo-rozwojową $(\mathrm{B}+\mathrm{R})$ per capita $\left(\mathrm{x}_{4}\right)$ oraz nakłady własne w sektorze przedsiębiorstw na działalność $\mathrm{B}+\mathrm{R}\left(\mathrm{x}_{5}\right)$

\begin{tabular}{|l|c|c|c|c|c|c|c|c|}
\hline \multirow{2}{*}{} & \multicolumn{2}{|c|}{$\mathbf{x}_{\mathbf{2}}$} & \multicolumn{2}{c|}{$\mathbf{x}_{\mathbf{3}}$} & \multicolumn{2}{c|}{$\mathbf{x}_{\mathbf{4}}$} & \multicolumn{2}{c|}{ x5 } \\
\cline { 2 - 10 } & 2006 & 2011 & 2006 & 2011 & 2006 & 2011 & 2008 & 2011 \\
\hline Lubelskie & 0,648 & 0,553 & 0,000 & 0,000 & 1,000 & 0,434 & 0,153 & 0,128 \\
\hline Podkarpackie & $\mathbf{1 , 0 0 0}$ & $\mathbf{1 , 0 0 0}$ & $\mathbf{0 , 5 2 9}$ & $\mathbf{1 , 0 0 0}$ & $\mathbf{0 , 8 7 5}$ & $\mathbf{1 , 0 0 0}$ & $\mathbf{1 , 0 0 0}$ & $\mathbf{1 , 0 0 0}$ \\
\hline Podlaskie & 0,203 & 0,000 & 0,764 & 0,432 & 0,514 & 0,031 & 0,217 & 0,023 \\
\hline Świętokrzyskie & 0,000 & 0,028 & 0,149 & 0,316 & 0,000 & 0,000 & 0,171 & 0,031 \\
\hline Warmińsko-mazurskie & 0,580 & 0,179 & 1,000 & 0,375 & 0,329 & 0,187 & 0,000 & 0,000 \\
\hline
\end{tabular}

Źródło: opracowanie własne na podstawie metody unitaryzacji zerowej

Jak wynika z tabeli 3, pod względem wartości nakładów inwestycyjnych oraz nakładów na działalność badawczo-rozwojową podkarpackie utrzymuje najwyższy wskaźnik wartości nakładów inwestycyjnych ogółem zarówno w roku 2006, jak i 2011 roku, przy czym różnica pomiędzy tym regionem a następnym w klasyfikacji pogłębiła się (w 2006 roku - 0,648 dla województwa lubelskiego, w 2011 roku - 0,553 dla tegoż samego regionu). Dla kategorii nakładów inwestycyjnych per capita w roku 2006 Podkarpacie zajmowało trzecią lokatę z współczynnikiem 0,529 (lider województwo warmińsko-mazurskie), w roku 2011 zaś osiagnęło pozycję dominującą (uzyskując dużą przewagę nad drugim w klasyfikacji województwem podlaskim - wskaźnik równy 0,432). Również w wypadku nakładów na $\mathrm{B}+\mathrm{R}$ per capita województwo podkarpackie 
odnotowało wzrost pozycji z drugiej w 2006 roku - 0,875 (na czele województwo lubelskie), na pierwszą w roku 2011 - drugie w klasyfikacji województwo lubelskie uzyskało wskaźnik 0,434. Utrzymana została pozycja lidera w kategorii nakładów własnych w sektorze przedsiębiorstw na działalność badawczo-rozwojową, przy czym różnica między regionem zajmującym drugie miejsce uległa powiększeniu (w 2008 0,217 dla Podlasia, w 2011 - 0,128 dla województwa lubelskiego). Jako rok porównawczy wykorzystano rok 2008 ze względu na brak danych dla lat wcześniejszych.

Ważnymi wyznacznikami poziomu konkurencyjności są wskaźniki dotyczące przedsiębiorstw, które współpracowały w zakresie działalności innowacyjnej, oraz tych przedsiębiorstw, które poniosły nakłady na działalność innowacyjną. Wskaźniki dla tych kategorii przedstawiono w tabeli 4.

Tabela 4. Przedsiębiorstwa przemysłowe, które współpracowały w zakresie działalności innowacyjnej $\left(\mathrm{x}_{6}\right)$, oraz przedsiębiorstwa, które poniosły nakłady na działalność innowacyjną $\left(\mathrm{x}_{7}\right)$

\begin{tabular}{|l|c|c|c|c|}
\hline \multirow{2}{*}{} & \multicolumn{2}{|c|}{$\mathbf{x}_{\mathbf{6}}$} & \multicolumn{2}{c|}{$\mathbf{x}_{\mathbf{7}}$} \\
\cline { 2 - 5 } & 2006 & 2011 & 2006 & 2011 \\
\hline Lubelskie & 0,494 & 0,250 & 0,156 & 0,752 \\
\hline Podkarpackie & $\mathbf{1 , 0 0 0}$ & $\mathbf{1 , 0 0 0}$ & $\mathbf{1 , 0 0 0}$ & $\mathbf{1 , 0 0 0}$ \\
\hline Podlaskie & 0,798 & 0,222 & 0,000 & 0,310 \\
\hline Świętokrzyskie & 0,371 & 0,000 & 0,056 & 0,349 \\
\hline Warmińsko-mazurskie & 0,000 & 0,250 & 0,133 & 0,000 \\
\hline
\end{tabular}

Źródło: opracowanie własne na podstawie metody unitaryzacji zerowej

W kategorii przedsiębiorstw przemysłowych, które współpracowały w zakresie działalności innowacyjnej, województwo podkarpackie utrzymało pozycję lidera, zwiększając dystans do drugiej pozycji (w 2006 roku było to województwo podlaskie z wynikiem 0,798, w roku 2011 - województwo warmińsko-mazurskie wspólnie z lubelskim, osiagając wskaźnik 0,250). Jednakże patrząc na kryterium ogółu przedsiębiorstw, które poniosły nakłady na działalność innowacyjną, widać tendencję odwrotną, czyli mimo utrzymania pozycji lidera następuje zwiększenie się liczby przedsiębiorstw, które poniosły nakłady na działalność innowacyjną w innych regionach niż Podkarpacie (w 2006 roku na drugim miejscu plasowało się województwo lubelskie 0,156, w 2011 zaś to samo województwo osiagnęło wskaźnik 0,752).

Sytuację jednostek z działalnością badawczo-rozwojową zaprezentowano w tabeli 5 . 
Tabela 5. Jednostki $\mathrm{z}$ działalnością badawczo-rozwojową ogółem $\left(\mathrm{x}_{8}\right)$ oraz jednostki $\mathrm{z}$ działalnością badawczo-rozwojową w sektorze przedsiębiorstw $\left(\mathrm{x}_{9}\right)$

\begin{tabular}{|l|c|c|c|c|}
\hline \multirow{2}{*}{} & \multicolumn{2}{|c|}{$\mathbf{x}_{\mathbf{8}}$} & \multicolumn{2}{c|}{$\mathbf{x}_{\mathbf{9}}$} \\
\cline { 2 - 5 } & 2006 & 2011 & 2006 & 2011 \\
\hline Lubelskie & 0,684 & 1,000 & 0,541 & 0,766 \\
\hline Podkarpackie & $\mathbf{1 , 0 0 0}$ & $\mathbf{0 , 9 2 3}$ & $\mathbf{1 , 0 0 0}$ & $\mathbf{1 , 0 0 0}$ \\
\hline Podlaskie & 0,132 & 0,115 & 0,108 & 0,000 \\
\hline Świętokrzyskie & 0,053 & 0,000 & 0,162 & 0,064 \\
\hline Warmińsko-mazurskie & 0,000 & 0,135 & 0,000 & 0,085 \\
\hline
\end{tabular}

Źródło: opracowanie własne na podstawie metody unitaryzacji zerowej

Województwo podkarpackie w roku 2006 było liderem pod względem liczby jednostek prowadzących działalność badawczo-rozwojową ogółem (na drugiej pozycji województwo lubelskie - 0,684). W 2011 roku utraciło pozycję lidera, ustępując miejsca regionowi lubelskiemu i z wynikiem 0,923 zajmowało drugą pozycję, mając znaczną przewagę nad trzecim w klasyfikacji województwem warmińsko-mazurskim $(0,135)$. Jeśli rozpatrywać to zagadnienie jedynie dla sektora przedsiębiorstw, Podkarpacie zajmuje pozycję lidera (zarówno w roku 2006, jak i w 2011). Jednakże zmniejsza się różnica pomiędzy nim a województwem lubelskim, które w roku 2006 uzyskało miarę 0,541, w roku 2011 zaś już 0,766 .

W tabeli 6 przedstawiono sytuację na rynku pracy w kontekście długotrwale bezrobotnych oraz osób zatrudnionych w działalności badawczo-rozwojowej. W kategorii bezrobotnych zarejestrowanych pozostających bez pracy powyżej roku województwo podkarpackie zdecydowanie pogorszyło swoją pozycję w stosunku do większości obszarów Polski Wschodniej. Wskaźnik 0,490 w roku 2006 zapewniał pozycję w środkowej części tabeli (gdzie liderem było podlaskie, drugie zaś lubelskie ze wskaźnikiem 0,612), w roku 2011 zmalał do zaledwie 0,077, co oznacza, że trudniejsza sytuacja bezrobotnych dłużej niż rok jest jedynie $w$ warmińsko-mazurskim. W pozostałych regionach sytuacja tych osób jest dużo lepsza - najkorzystniejsza jest w lubelskim, a następnie świętokrzyskim (2011 rok - 0,923) oraz podlaskim (2011 - 0,846). Podczas analizy konkurencyjności regionu jako liczbę osób zatrudnionych w działalności badawczo-rozwojowej widać zdecydowany trend wzrostowy w województwie podkarpackim: z wartości wskaźnika 0,296 w roku 2006 do 0,750 w roku 2011, gdzie przewodzi zarówno w roku 2006, jak i 2011 województwo lubelskie. Warto zwrócić uwage na niewielkie zmiany wzrostowe w pozostałych regionach. Ciekawie wygląda statystyka zatrudnienia $\mathrm{W} B+\mathrm{R}$ w sektorze przedsiębiorstw. W tej kategorii województwo podkarpackie miało w 2006 roku przewagę w stosunku do innych obszarów (drugie było lubelskie ze wskaźnikiem 0,460), która została jeszcze powiększona w roku 2011 - następny region po Podkarpaciu - lubelskie - osiągnął wynik 0,137. 
Tabela 6. Bezrobotni zarejestrowani pozostający bez pracy dłużej niż rok $\left(\mathrm{x}_{10}\right)$, zatrudnieni w $\mathrm{B}+\mathrm{R}$ ogółem $\left(\mathrm{x}_{11}\right)$ oraz zatrudnieni w $\mathrm{B}+\mathrm{R}$ w sektorze przedsiębiorstw $\left(\mathrm{x}_{12}\right)$

\begin{tabular}{|l|c|c|c|c|c|c|}
\hline \multirow{2}{*}{} & \multicolumn{2}{|c|}{$\mathbf{x}_{\mathbf{1 0}}$} & \multicolumn{2}{c|}{$\mathbf{x}_{\mathbf{1 1}}$} & \multicolumn{2}{c|}{$\mathbf{x}_{\mathbf{1 2}}$} \\
\cline { 2 - 7 } & 2006 & 2011 & 2006 & 2011 & 2006 & 2011 \\
\hline Lubelskie & 0,612 & 1,000 & 1,000 & 1,000 & 0,460 & 0,137 \\
\hline Podkarpackie & $\mathbf{0 , 4 9 0}$ & $\mathbf{0 , 0 7 7}$ & $\mathbf{0 , 2 9 6}$ & $\mathbf{0 , 7 5 0}$ & $\mathbf{1 , 0 0 0}$ & $\mathbf{1 , 0 0 0}$ \\
\hline Podlaskie & 1,000 & 0,846 & 0,212 & 0,294 & 0,044 & 0,102 \\
\hline Świętokrzyskie & 0,347 & 0,923 & 0,000 & 0,000 & 0,158 & 0,079 \\
\hline Warmińsko-mazurskie & 0,000 & 0,000 & 0,162 & 0,196 & 0,000 & 0,000 \\
\hline
\end{tabular}

Źródło: opracowanie własne na podstawie metody unitaryzacji zerowej

Ostatnią cechą diagnostyczną, jaką wybrano do analizy poziomu konkurencyjności województwa podkarpackiego, był wskaźnik syntetyczny atrakcyjności inwestycyjnej województw pochodzący z cyklicznych raportów Instytutu Badań nad Gospodarką Rynkową i Fundacji Konrada Adenauera Atrakcyjność inwestycyjna województw i podregionów Polski z lat 2007 i 2012. Częściami składowymi tego wskaźnika są ${ }^{11}$ :

- dostępność transportowa;

- zasoby i koszty pracy;

- rynek zbytu;

- infrastruktura gospodarcza;

- infrastruktura społeczna;

- bezpieczeństwo powszechne;

- aktywność województw wobec inwestorów.

Tabela 7. Atrakcyjność inwestycyjna regionów

\begin{tabular}{|l|c|c|}
\hline \multirow{2}{*}{} & \multicolumn{2}{|c|}{$\mathbf{x}_{\mathbf{1 3}}$} \\
\cline { 2 - 3 } & 2006 & 2011 \\
\hline Lubelskie & 0,206 & 0,750 \\
\hline Podkarpackie & $\mathbf{0 , 6 7 6}$ & $\mathbf{1 , 0 0 0}$ \\
\hline Podlaskie & 0,000 & 0,000 \\
\hline Świętokrzyskie & 0,412 & 0,375 \\
\hline Warmińsko-mazurskie & 1,000 & 0,625 \\
\hline
\end{tabular}

Źródło: opracowanie własne na podstawie metody unitaryzacji zerowej

W tabeli 7 przedstawiono znormalizowany wskaźnik dla regionów Polski Wschodniej. Województwo podkarpackie w roku 2011 zwiększyło swoją atrakcyjność inwestycyjną w stosunku do roku 2006, co spowodowało, że zostało liderem spośród analizowanej grupy regionów, w roku porównawczym osiągając drugą pozycję ze wskaźnikiem 0,676.

\footnotetext{
${ }^{11}$ Atrakcyjność inwestycyjna województw i podregionów Polski 2008, red. T. Kalinowski, Instytut Badań nad Gospodarką Rynkową, Gdańsk 2008; Atrakcyjność inwestycyjna województw i podregionów Polski 2012, red. M. Nowicki, Instytut Badań nad Gospodarką Rynkową, Gdańsk 2012.
} 
W roku 2011 na drugiej pozycji uplasowało się województwo lubelskie $(0,750)$, na trzeciej zaś znalazł się lider klasyfikacji w roku 2006 - województwo warmińskomazurskie z wartością wskaźnika 0,625.

Jeśli wziąć pod uwagę syntetyczny wskaźnik konkurencyjności regionów (tab. 8.), województwo podkarpackie ma dominująca pozycję konkurencyjną względem pozostałych obszarów Polski Wschodniej.

Tabela 8. Syntetyczny wskaźnik konkurencyjności regionów

\begin{tabular}{|l|c|c|c|c|c|}
\hline & $\mathbf{2 0 0 6}$ & $\begin{array}{c}\text { Pozycja } \\
\text { w rankingu }\end{array}$ & $\mathbf{2 0 1 1}$ & $\begin{array}{c}\text { Pozycja } \\
\text { w rankingu }\end{array}$ & $\begin{array}{c}\text { Zmiana } \\
\mathbf{2 0 1 1 / 2 0 0 6}\end{array}$ \\
\hline Lubelskie & 5,954 & 2 & 6,803 & 2 & $14 \%$ \\
\hline Podkarpackie & $\mathbf{9 , 9 7 1}$ & $\mathbf{1}$ & $\mathbf{1 0 , 7 5 0}$ & $\mathbf{1}$ & $\mathbf{8 \%}$ \\
\hline Podlaskie & 4,680 & 3 & 3,012 & 4 & $-36 \%$ \\
\hline Świętokrzyskie & 2,878 & 5 & 3,164 & 3 & $10 \%$ \\
\hline Warmińsko-mazurskie & 4,151 & 4 & 2,745 & 5 & $-34 \%$ \\
\hline
\end{tabular}

Źródło: opracowanie własne na podstawie metody unitaryzacji zerowej

Wskaźnik ten zwiększył się z 9,971 w roku 2006 do 10,750 w roku 2011, do daje około 8-procentowy wzrost. Przy czym należy zwrócić uwagę na województwo lubelskie, które w obydwu rozpatrywanych okresach zajmuje drugie miejsce. W roku 2006 uzyskało 5,954, w 2011 zaś - 6,803. Oznacza to wzrost roku bazowego w stosunku do roku porównawczego o około $14 \%$. Jest to największy wzrost poziomu konkurencyjności w ujęciu 2011/2006, co oznacza, że województwo podkarpackie mimo wartościowego wzrostu poziomu konkurencyjności rozwija ją wolniej niż województwo lubelskie.

\section{WNIOSKI}

Województwo podkarpackie jest liderem pod względem nakładów własnych w sektorze przedsiębiorstw na działalność B + R, liczby przedsiębiorstw przemysłowych, które współpracowały w zakresie działalności innowacyjnej, oraz zatrudnionych w $\mathrm{B}+\mathrm{R}$ w sektorze przedsiębiorstw. Zwłaszcza ta ostatnia kategoria, w kontekście zwiększania się zatrudnionych w działalności badawczo-rozwojowej ogółem, może stanowić o pozycji konkurencyjnej Podkarpacia. Do tego należy dodać równie dużą przewagę w nakładach własnych na działalność B + R w sektorze przedsiębiorstw. Widoczna różnica poziomu wskaźników występuje także w pozostałych kategoriach dotyczących nakładów, czyli w wartości nakładów inwestycyjnych ogółem, nakładów inwestycyjny per capita i nakładów na $\mathrm{B}+\mathrm{R}$ per capita.

Oceniając poziom konkurencyjności województwa podkarpackiego na tle pozostałych regionów Polski Wschodniej, trzeba stwierdzić bardzo niski poziom wskaźnika dla PKB per capita, co może okazać się pewną tendencją słabnącego potencjału ogólnego gospodarki. Charakterystyczne jest zwiększanie się liczby zarejestrowanych bezrobotnych pozostających bez pracy dłużej niż rok. Może to świadczyć o występowaniu strukturalnego bezrobocia na Podkarpaciu. Pełna odpowiedź na pytanie o sytuację na rynku pracy wymagałaby analizy struktury bezrobotnych między innymi z podziałem na wiek i wykształcenie. 
W przeprowadzonej analizie konkurencyjności regionów wykazano, że PKB per capita nie jest czynnikiem decydującym o pozycji konkurencyjnej województwa podkarpackiego. Oznacza to, że region może mieć wysoki poziom wskaźnika konkurencyjności mimo niskiego wskaźnika PKB na osobę.

\section{LITERATURA}

[1] Kudłacz T., Analiza pięciu strategii regionalnych województw Polski wschodniej i problemów stykowych pomiędzy województwami Polski wschodniej z innymi regionami, Ministerstwo Rozwoju Regionalnego, Warszawa 2006,

http://www.mrr.gov.pl/rozwoj_regionalny/poziom_regionalny/strategia_rozwoju_polski_ wschodniej_do_2020/zespol_ds_strategii/Documents/Analiza_5_strategii_regionalnych_kudla cz.pdf (dostęp: 11.03.2010).

[2] Program Operacyjny Rozwój Polski Wschodniej 2007-2013. Narodowe Strategiczne Ramy Odniesienia 2007-2013, Ministerstwo Rozwoju Regionalnego, Warszawa 2012.

[3] Walenia A., Zastosowanie metody statystycznej unitaryzacji zerowej do oceny możliwości absorpcji środków Unii Europejskiej przez sektor samorzqdowy Podkarpacia, „Studia i Prace Kolegium Zarządzania i Finansów” 2009/91.

[4] Obrębski M., Mierniki rozwoju regionalnego, [w:] Metody oceny rozwoju regionalnego, red. Strahl D., Wydawnictwo Akademii Ekonomicznej we Wrocławiu, Wrocław 2006.

[5] Bieńkowski W., Reaganomika i jej wptyw na konkurencyjność gospodarki amerykańskiej, PWN, Warszawa 1995.

[6] Surówka A., Badanie zróżnicowania województw pod względem konkurencyjności, „Zeszyty Naukowe Uniwersytetu Rzeszowskiego", Rzeszów 2007.

[7] Olesiuk A., Konkurencyjność regionów a parki technologiczne i klastry przemystowe, Oficyna Wydawnicza Branta, Bydgoszcz-Warszawa 2009.

[8] Pietrzyk I., Polityka regionalna Unii Europejskiej i regiony w państwach członkowskich, PWN, Warszawa 2000.

[9] Atrakcyjność inwestycyjna województw i podregionów Polski 2008, red. T. Kalinowski, Instytut Badań nad Gospodarką Rynkową, Gdańsk 2008.

[10] Atrakcyjność inwestycyjna województw i podregionów Polski 2012, red. M. Nowicki, Instytut Badań nad Gospodarką Rynkową, Gdańsk 2012.

\section{COMPETITIVENESS OF PODKARPACKIE PROVINCE WITH OTHER REGIONS OF EASTERN POLAND}

The article discusses the problem of the competitiveness of regions, in particular interregional competition and an analysis of the competitiveness of the Subcarpathian province to other provinces of Eastern Poland (understood in accordance with the nomenclature of the Operational Programme Development of Eastern Poland - i.e. the provinces of Warmia and Mazury, Lublin, Subcarpathian, Podlasie and Świętokrzyskie). Assessment of the competitive method was tested using the ranking. The concept of competitiveness is defined by many authors, however, the most often with a reference to the companies.

Competitiveness of regions as an economic concept has been operating relatively recently, and therefore is not conducive to unequivocally defining it and the more defining of its gauges. For the purposes of this study the competitiveness of the regions was investigated on the basis of several indicators characterizing the various aspects of economic development. Among these measures were, among others, GDP per capita expenditure on research and development, the number of businesses incurring expenditure on innovation activities and investment attractiveness of regions. The analysis of the 
competitiveness of regions showed that the GDP per capita is not a decisive factor in the competitive position of the Subcarpathian province. This means that the region may have a high level of competitiveness index, in spite of the low rate of GDP per capita. For the validity of this thesis speaks an example of Subcarpathian province that is a leader in terms of investment in their business sector on $\mathrm{R} \& \mathrm{D}$, as well as in a number of industrial companies that cooperated in the field of innovative activity. It is at this region is characterized by one of the lowest GDP per capita.

Keywords: regional competitiveness, Polish and Eastern regions, Subcarpathian province, the ranking method, the outermost regions

\section{DOI: $10.7862 /$ rz.2013.mmr.43}

Tekst złożono w redakcji: wrzesień 2013

Przyjęto do druku: grudzień 2013 